\author{
Katarzyna Malinowska-Woźniak* \\ Maria Wysocka** \\ Krzysztof Kubasik***
}

\title{
THE PRINCIPLE OF UNITY OF THE CIVIL LAW VS COHESION \\ OF COMMERCIAL LAW AND FAMILY LAW REGULATIONS \\ (NATIONWIDE SCIENTIFIC CONFERENCE, SZCZECIN, 19 OCTOBER 2018)
}

The Nationwide Scientific Conference "The principle of unity of the civil law vs cohesion of commercial law and family law regulations," organised by the Civil and Commercial Law Department of the Law and Administration Faculty of the University of Szczecin in cooperation with the Institute of Legal Sciences of the Polish Academy of Sciences, was held in the Senate Hall of the University of Szczecin on 19 October 2018. Held under the patronage of the President of the City of Szczecin, the conference was attended by 50 participants from 16 research centres who presented 10 papers and 8 communiqués.

The first to take the floor was the Dean of the Law and Administration Faculty of the University of Szczecin dr hab. prof. US Zbigniew Kuniewicz, who

* Katarzyna Malinowska-Woźniak, Ph.D., Faculty of Law and Administration, University of Szczecin, e-mail address: katarzyna.malinowska-wozniak@usz.edu.pl. ORCID: 0000-00023442-7905.

** Maria Wysocka, MA, Faculty of Law and Administration, University of Szczecin, e-mail address: maria.wysocka@usz.edu.pl. ORCID: 0000-0003-0592-6622.

*** Krzysztof Kubasik, MA, Faculty of Law and Administration, University of Szczecin, e-mail address: krzysztof.kubasik@usz.edu.pl. ORCID: 0000-0002-3122-4539. 
welcomed the conference participants, including His Magnificence Rector of the University of Szczecin prof. zw. dr hab. Edward Włodarczyk and Vice President of the City of Szczecin dr hab. prof. US Daniel Wacinkiewicz, to whom he subsequently gave the floor. The conference was divided into 3 panels moderated by prof. dr hab. Andrzej Kidyba, dr hab. prof. US Zbigniew Kuniewicz and prof. dr hab. Adam Olejniczak respectively, and ended with a discussion led by dr hab. prof. US Marek Andrzejewski.

The first speaker was dr hab. prof. INP PAN Monika Tarska from the Institute of Legal Sciences of the Polish Academy of Sciences, who presented a paper titled "Unity of the civil law vs legal regulation of commercial companies." The speaker began with a historical background of the entry into force of the Civil Code in 1965, which introduced the principle of unity of the civil law, and the subsequent entry into force of the Commercial Companies Code. In her speech, she highlighted the following groups of issues: the essence, scope and applicability of the freedom of contract principle in the area of commercial companies regulations; relationship of civil law provisions on legal transactions, in particular contracts, with issues concerning commercial companies contracts and invalidity of contracts; the concept of a legal transaction and a corporate body, invalidity of a legal transaction, challenge ability of a resolution adopted by a meeting of partners and general meeting and the so-called non-existent resolutions; the legal and property status of spouses in a situation where one of them is a participant in a company; synchronisation of the provisions of the Act on the National Court Register concerning the registration proceedings with the systemic provisions of the Commercial Companies Code.

The second speaker was dr hab. prof. UW Łukasz Błaszczak from the University of Wrocław, who presented a paper titled "The issue of acceptability of an action pursuant to Article 189 of the Code of Civil Procedure for annulment of resolutions vs the autonomous regime of challenging resolutions under the Commercial Companies Code." He pointed out that the case law and the doctrine lack unanimity concerning the scope of applicability of the provisions of the Civil Code on requirements for and effects of defectiveness of legal transactions, particularly Article 58 of the Civil Code, to resolutions. He also discussed the topic of the so-called non-existent resolutions, as well as highlighted the lack of unanimity of the jurisprudence and the doctrine in this respect. His further deliberations concerned the issue of legal interest, and the speaker expressed the view 
that the jurisprudence errs in linking legal interest with actual interest and that it is wrong to assume that if an entity has economic interest, then it automatically has legal interest. He also discussed the provision laid down in Article 17 Point $4^{2}$ of the Code of Civil Procedure as a possible ground for initiating an action for annulment of a resolution, and concluded by assessing the acceptability of an action for declaring a resolution annulled or non-existent in the context of the constitutional principle of equality.

The next paper titled "Analysis of applicability of private law to the public sector as an inspiration for the development of the civil law methodology" was presented by dr hab. prof. UAM Rafał Szczepaniak from the Adam Mickiewicz University in Poznań. The speaker noted that a number of civil law institutions are used also in the public law sector, which opens a discussion on the principle of unity of civil law at different levels. Law is principally divided into the private law and public law sectors, with civil law relationships occupying a vast area. There are institutions in civil law with a dominant technical component which would enable their intersectoral application. However, there are also institutions in which the axiological component dominates - such as a contract and ownership - and their application to the public sector leads to a significant distortion of their essence, hence these institutions cannot be understood merely as specific tools. The speaker presented the issue of open pension funds and a judgement of the Constitutional Tribunal passed in this context in 2015. He drew attention to the phenomenon of constitutionalisation of civil law, which enriches the civil law methodology by demonstrating the limits of civil law, which is linked also with the protection of fundamental rights. In summary of his speech, prof. R. Szczepaniak postulated the need to isolate the public sector's civil law as a civil law branch equal to other civil law branches. The last speaker to take the floor in the first panel was dr hab. prof. UMK Konrad Zacharzewski from the Nicolaus Copernicus University in Torun, who presented the principle of unity of civil and commercial law in stock exchange law following implementation of the MiFID 2 Directive of 2014.

The second panel started with a speech of dr hab. Grzegorz Kozieł from the Maria Curie-Skłodowska University in Lublin titled "Acquisition of a shareholding in an EEIG established in the Republic of Poland funded from assets jointly held in the regime of joint property of spouses in the context of becoming a member of that grouping." The speaker began with pointing out that although EEIGs 
are not typical business operators in the strict sense of this term, they are entered into the register of entrepreneurs of the National Court Register and are allowed to conduct business activity for and in the interest of their members. Acquisition of a shareholding in an EEIG for funds from joint spousal property entails inclusion of that shareholding in the joint property. Consequences of such acquisition in the area of membership in the EEIG can be perceived in a non-uniform manner, especially depending on whether the shareholding in the EEIG is acquired by both spouses (i.e. it is acquired jointly) or by one of them. The speaker noted the absence of cohesion in this area as regards family law and commercial law regulations, which should be removed by means of introducing a comprehensive regulation regarding consequences of acquisition of "share rights" in commercial companies and other similar organisational entities, including in particular EEIGs and mutual insurance institutions.

The next paper was presented by dr Robert Słabuszewski from the Jacob of Paradies University in Gorzów Wielkopolski. In his presentation, the speaker raised the issue of division of joint property of spouses who are shareholders in commercial companies. According to dr R. Słabuszewski, interests in a partnership and units of participation in capital companies may be part of joint spousal property, which should, however, be clearly distinguished from holding the status of a shareholder in a given company. Analysing methods of division of assets known in civil law, the speaker evaluated their applicability to division of interests as well as shares and holdings between the spouses. He also discussed the impact of restrictions on the trade in participation rights on admissibility and manner of their division. He explained the method of establishing the value of the right being divided (in terms of status, price and method of valuation).

The paper presented by dr Aleksandra Sikorska-Lewandowska from the Nicolaus Copernicus University in Torun concerned the legal nature of resolutions of capital company bodies and the issue of their challenge ability in the light of the provisions of the Commercial Companies Code and the Civil Code. The speaker began with discussing the theory of capital company bodies and pointing out that, due to their specific nature, resolutions adopted by such bodies belong to the category of corporate legal actions. In accordance with the current case law and views of the doctrine, on the grounds of the principle of unity of civil law, one must reject applicability of the provisions of the Commercial Companies Code on challenging resolutions of general meetings per analogiam with chal- 
lenging resolutions of supervisory boards and management boards. According to the speaker, this leads to application of different regimes of challenging resolutions of capital company bodies and linking the challenge ability of resolutions of supervisory boards and management boards with their legal nature in the absence of such linking in the case of resolutions of shareholder meetings.

The second panel was closed with communiqués. Dr Paweł Lewandowski from the University of Warmia and Mazury in Olsztyn raised the issue of seconding a member of the supervisory board of a limited liability company to seat in the management board. The communiqué by dr Tomasz Kozak from the European University of Law and Administration in Warszawa concerned the liability of the spouse of a partner in a partnership following cessation of joint spousal property. The communiqué delivered by mgr Maria Wysocka from the University of Szczecin covered the issue of legal nature of membership and participation in capital companies. Mgr Krzysztof Kubasik from the University of Szczecin delivered a communiqué concerning a contract for the provision of services between a member of the management board and a limited liability company in the context of the principle of unity of civil law.

The third panel, moderated by prof. dr hab. Adam Olejniczak from the Adam Mickiewicz University in Poznań, was started by speech of dr Mariusz Zelek from the Adam Mickiewicz University in Poznań, who presented a paper titled "Fault in civil, criminal, family and copyright law - input to the discussion on the notion of fault in Polish law". The speaker noted that the Polish legal system often refers to fault as a circumstance relevant to the existence of specific legal consequences while at the same time not providing a legal definition of the term. He gave the examples of family law (fault in marital breakdown), civil law (fault as a circumstance of liability for damages) and criminal law (fault as a circumstance that legitimises and limits criminal liability). He highlighted that although the said terms refer to a negative assessment of one's behaviour, a closer analysis shows material differences in the construction and elements of fault in the respective areas. This in turn, according to the speaker, demands one to consider whether fault can be perceived as a universal category or in fact there are "different faults" in respective fields of law.

Next to take the floor was dr Dominika Mróz-Krysta from the Jagiellonian University, who discussed the issue of return of expenses incurred from joint spousal property on personal property of one of them in the context of the right 
of retention under Article $461 \S 2$ of the Civil Code. The speaker pointed out that the issue had arisen from a specific civil case. She then proceeded to giving the facts of the case according to which a divorced spouse suing for settlement of expenses incurred from the joint property on the other spouse's personal property used the plea of retention provided for in Article $461 \S 1$ of the Civil Code. The personal property component on which expenses had been incurred was a real property satisfying the family's housing needs. The court made the eviction of the divorced spouse from the real conditional on settlement of the expenses incurred from the joint spousal property on that real property. According to the speaker, such ruling makes one formulate a question whether it is possible to use the analogy with Article $461 \S 2$ of the Civil Code which provides for exceptions from the right of retention.

The next speaker to take the floor was dr Maciej Domański from the University of Warsaw, who presented the issue of the defectiveness of concluding a marriage in the light of traditional civil law sanctions concerning defectiveness of legal actions. The speaker pointed out that the jurisprudence noticeably lacks research into the specific nature of family law relationships and events. In his speech, he analysed the provisions of the Family and Guardianship Code in the area of sanctions connected with faulty conclusion of a marriage (annullability of marriage, matrimonium non existens) in reference to similar civil law sanctions concerning defectiveness of legal transactions.

The last part of the third panel included communiques. Dr Ewa Lewandowska from the University of Warmia and Mazury in Olsztyn presented the issue of concluding a marriage of convenience as an unsolved practical problem. The next speaker was dr Jerzy Akińcza, also from the University of Warmia and Mazury in Olsztyn, who discussed the model of a partnership as the basis for settling property in civil partnerships. The next communique was presented by $\mathrm{dr}$ Katarzyna Malinowska-Woźniak from the University of Szczecin, who raised the issue of the scope of the spouse's consent referred to in Article 37 of the Family and Guardianship Code for the other spouse to make a legal transaction. The last speaker was mgr. Adriana Tomczyk from the University of Szczecin, who discussed the issue of annulling a donation to the beneficiary spouses remaining in a statutory property regime.

After the end of the third panel, a discussion began, moderated by dr hab. prof. US Marek Andrzejewski from the University of Szczecin. The papers deliv- 
ered during the conference inspired the participants to speak. Dr hab. prof. INP PAN Monika Tarska presented her thoughts as the first one and pointed out that it is not correct to use the term "corporate shareholding" to refer to all rights and obligations of a partner in a partnership. The Commercial Companies Code cannot take precedence over the Family and Guardianship Code. Prof. Monika Tarska opposed the concept of the multiplication of the company share in a partnership. In her opinion the legislator's intervention in the field of normative regulation of partners' participation in commercial companies is now needed.

Dr Robert Słabuszewski pointed out that the notion of a company share is an acronym and does not change the way the concept of all rights and obligations in a partnership is understood. He also stated that in his opinion, the possibility of joining the company by a partner's spouse is always subject to the control of other partners due to the regulation contained in Article 10 of the Commercial Companies Code. In turn, dr hab. Grzegorz Kozieł stated that he agrees with the prof. M. Tarska on the need for legislative changes with regard to the participation of spouses in partnerships.

Another speaker was a prof. of the University of Gdańsk, dr hab. Małgorzata Balwicka-Szczyrba, who referred to dr E. Lewandowska's speech on the apparent marriage. She suggested that consideration should be given to whether the existence of a formal element when the marriage is celebrated, such as the presence of the head of the Registry Office or a priest, does not prevent to declare apparency of the declaration of marriage.

The next speaker was professor of the John Paul II Catholic University of Lublin, dr hab. Andrzej Herbet, who stated that the unity of civil law is necessary and of fundamental importance. Hence the topic of the conference is very relevant. The differences in the detailed approach result from petrifying the legal status of general regulations. This has been confirmed by the need to search for definitions of fundamental concepts, such as the right of membership, which was aptly pointed out by mgr M. Wysocka. Consequently, it is necessary to revise the basic structures of civil law. On the other hand, an action for determination under Article 189 of the Code of Civil Procedure cannot concern the determination of non-existence of a resolution, but an action can be brought for determination of non-existence of a legal relationship whose source is a defective resolution. The legal nature of the judgment declaring the resolution as invalid is fundamental. However, prof. A. Herbet did not agree with the view expressed by the Supreme 
Court that the judgment declaring the resolution as invalid is of constitutive nature, because in such case no other court in other proceedings won't be able to declare this invalidity, including the registration court.

His own reflections were also presented by prof. of the Adam Mickiewicz University, dr hab. Rafał Szczepaniak, who pointed out that he agrees with prof. A. Herbet that the conclusions of the application of private law in public law are that a public entity, when performing activities regulated by private law, must still comply with the rules set out by public law.

Next, prof. of the University of Szczecin, dr hab. Zbigniew Kuniewicz, took the floor and stated that he agrees with prof. A. Herbet on the imperfection of the general part of civil law. He also noted that there is an inconsistency between the regulation contained in Article 21 of the Commercial Companies Code and the provisions of the Act on the National Court Register. He questioned the need for the legislator to indicate the reasons for the non-existence of resolutions. Referring to the concept of the resolution as an intra-corporate act, presented by $\mathrm{dr}$ A. Sikorska-Lewandowska, he pointed out the need to search for solutions using basic civilistic constructions, rather than creating new ones.

Summarizing the speeches of the speakers, dr Mariusz Zelek drew attention to the necessity of expanding the catalogue of entities in the Civil Code, in particular due to the regulation of tortious liability because of the so-called fault of the authority. He also noted that the obligation to contracting under private law exists, but failure to do so results in public law sanctions only. In turn, dr Jerzy Akińcza, while taking the floor during the discussion, stated that the increasing appropriation of private law by public law is unacceptable. He added that the direct application of Article 189 of the Code of Civil Procedure to determine the non-existence of resolutions, and not only to determine the non-existence of legal relationships arising from them, does not violate the legal order. Next, dr Ewa Lewandowska pointed out in her statement that she was considering the issue of non-existence of marriage as a result of marriage of convenience, but in her opinion, since the parties made some statements and third parties got acquainted with them, we cannot speak about the non-existence of such a legal relationship. Dr Grzegorz Sikorski referred to the issue of delegating a member of the Supervisory Board to perform functions in the Management Board of a limited liability company. In his opinion, the conclusion of such a provision in the articles of association does not violate the principle of freedom of agreement, and moreover, 
it is a good solution in a situation where in a limited liability company the management board is appointed by the shareholders' meeting, because the shareholders obtain time to supplement the composition of the management board. Dr hab. Konrad Zacharzewski, prof. of the Nicolaus Copernicus University, also spoke. He pointed out that diligence is a duty under contract, but the concept of diligence may have a universal meaning. In addition, he stated that causa amore is not the cause of the marriage, and therefore the legislator may sanction a marriage of convenience in various ways, e.g. in such a way that it will not have any effect on the acquisition of citizenship.

At this point, the discussion ended and prof. Z. Kuniewicz took the floor. Summing up the conference he thanked for interesting and substantive speeches and inspiring voices during the discussion. He announced another conference organized by the Law and Administration Faculty of the University of Szczecin and invited participants to take part in it. 